\title{
Protocol for growing Kankakee mallow
}

(Iliamna remota)

Roberta (M ountz) Flood, David Horvath, and Gary BIessman

KEYWORDS: container nursery, endangered plant, $M$ alvaceae NOMENCLATURE: Taft and others (1997)

K ankakee mallow (Iliamna remota $\mathrm{G}$ reene [M alvaceae]) is an endangered Illinois prairie plant. Plants we propagate are outplanted on a variety of mesic prairie sites, including state parks, highway roadsides, and limited private lands. We start Kankakee mallow in a fullycontrolled greenhouse in containers, and following this protocol, plants are ready in about 7 to 11 mo.

We grow Kankakee mallow only when requested for special projects. The plant is easy to propagate using a regime similar to that used for a variety of prairie forbs at $M$ ason State N ursery in Illinois.

\section{Seed Collection, Cleaning,} and Pretreatments

Flowering occurs from about 14 June to 10 September. Seeds are collected by hand from nursery stock on 15 September. After drying, seeds are run dry through a $D$ ybvig macerator [equipment described in D umroese and others (2000)], then the Grinder (nursery-produced machine that helps break-up the seed capsules), and again dry through the $D$ ybvig. We remove the seeds and run them through the Clipper with a top screen of 7 , a bottom screen of $1 / 25$, and the Clipper fan on low. It takes about $225 \mathrm{~g}$ $(8 \mathrm{oz}$ ) of seeds to sow either 64 flats of the Ropak M ultiPot \#6, or 24 flats of the Ropak Multi-Pot \#3 or \#4 (Table 1). O nce clean, seeds are cold-moist stratified as follows: mix seeds with an equal volume of vermiculite, lightly dampen the mixture, place into a plastic bag, and refrigerate at 1 to $2^{\circ} \mathrm{C}$ (34 to $36^{\circ} \mathrm{F}$ ) for 3 to 4 mo.

\section{Sowing and Medium} We use sterile, Pro-M ix PGX (3:1; peat moss:vermiculite) amended with equal amounts of vermiculite and perlite (10:1 Pro-M ix:amendment) and $4.7 \mathrm{~kg} / \mathrm{m}^{3}\left(8.4 \mathrm{lb} / \mathrm{yd}^{3}\right)$ 0 smocote controlled release fertilizer $\left(17 \mathrm{~N}: 6 \mathrm{P}_{2} \mathrm{O}_{5}: 10 \mathrm{~K}_{2} 0 ; 8\right.$ to 9 mo release rate at $\left.21^{\circ} \mathrm{C}\left[70^{\circ} \mathrm{F}\right]\right)$. $G$ ently tap the containers to ensure the medium is settled properly.

Three crops are started in the greenhouse with the first in late D ecember and the last no later than the end of $M$ arch. We broadcast sow seeds by hand, trying to sprinkle 3 to 5 seeds per cell because seed purity rates vary from year to year see Kankakee on page 14

\begin{tabular}{|c|c|c|c|c|c|c|}
\hline \multicolumn{7}{|c|}{ TA B LE 1} \\
\hline \multicolumn{7}{|c|}{ Container types used for growing Kankakee mallow } \\
\hline \multirow{3}{*}{$\begin{array}{l}\text { Ropak } \\
\text { Multi-Pot }\end{array}$} & \multicolumn{6}{|c|}{ Cavity characteristics } \\
\hline & \multicolumn{2}{|c|}{ Volume } & \multicolumn{2}{|c|}{ Depth } & \multicolumn{2}{|c|}{ Density } \\
\hline & $\mathrm{ml}$ & $i^{3}$ & $\mathrm{~cm}$ & in & $\mathrm{m}^{2}$ & $\mathrm{ft}^{2}$ \\
\hline \#3 & 98 & 6 & 12 & 4.8 & 441 & 41 \\
\hline$\# 4$ & 148 & 9 & 17 & 6.6 & 441 & 41 \\
\hline$\# 6$ & 98 & 6 & 12 & 4.8 & 581 & 54 \\
\hline
\end{tabular}


Kankakee from page 13 and it is easier to thin than to transplant. Seeds are covered to $1 X$ their depth with the same growing medium. A dibble board or roller is used to gently press seeds and the top-dressing into cells.

\section{Growing the Plants}

D uring germination, we set greenhouse temperatures at 21 to $26^{\circ} \mathrm{C}\left(70\right.$ to $\left.80^{\circ} \mathrm{F}\right)$ during the day and 18 to $24{ }^{\circ} \mathrm{C}\left(65\right.$ to $75^{\circ} \mathrm{F}$ ) at night. U sually $75 \%$ germination is reached in about 2 to 3 wk. We do not use photoperiod control. Plants are watered by hand during germination using a "gentle shower" setting on the nozzle to prevent seed from splashing out.

O nce true leaves (not cotyledons) appear, we begin fertilization, starting with $50 \mathrm{ppm} \mathrm{N}$ of Peters Acid Special (21N :7P $\mathrm{O}_{5}: 7 \mathrm{~K}_{2} \mathrm{O}$ ) once a week, gradually increased to 200 ppm N over the next few weeks (Peters Liquid or R apid Grow fertilizers also work well). Plants are irrigated in the morning by soaking for 20 to $30 \mathrm{~min}$. M orning irrigations allow foliage to dry out during the day. After applying fertilizer, we irrigate with plain water at least 30 s to rinse fertilizer residue off the foliage to prevent burning.
Plants are thinned to 2 plants per cell before roots are too extensive. When foliage reaches 20 to $25 \mathrm{~cm}$ ( 8 to $10 \mathrm{in}$ ), we prune plants back to 7 to $10 \mathrm{~cm}$ (3 or $4 \mathrm{in}$ ), easily accomplished by turning containers on their sides and cutting with scissors or sheers. Clippings are removed from containers to prevent disease spread.

The first greenhouse crop is moved to a hoop house in late January or early February. Before moving, we acclimate plants by reducing the fertilization rate to 50 ppm $\mathrm{N}$ and decreasing greenhouse daytime temperatures to 13 to $15^{\circ} \mathrm{C}$ (55 to $60^{\circ} \mathrm{F}$ ). The second and third crops are moved directly to the shadehouse in April and M ay. Again, greenhouse controls and fertilization rates are adjusted in preparation for the move. Plants that reach 20 to 25 $\mathrm{cm}$ in height (8 tol0 in) while in the shadehouse are also pruned.

Plants are ready for shipment in 7 to 11 mo depending on weather and root development. Because it is a forb, we do not have a particular target height or root collar diameter, but a firm root plug is required. We strongly encourage fall shipment to the customer. For plugs not shipped for fall planting season, we remove dead foliage and place the plants in plastic bags (to ensure roots stay moist) and store them in cold rooms above freezing, preferably 4 to

$10^{\circ} \mathrm{C}$ ( 40 to $50^{\circ} \mathrm{F}$ ). Plants can be stored approximately 4 to $6 \mathrm{mo}$. Plugs may be shipped at any time as long as the receiver has cold storage.

\section{References}

Dumroese RK, Pequignot S, Horvath D. 2000. Mason State $\mathrm{N}$ ursery: a model for prairie plant production. $N$ ative Plants Journal 1:10-17

Taft JB, W ilhelm GS, Ladd DM, M asters LA. 1997. Floristic quality assessment for vegetation in Illinois, a method for assessing vegetation integrity. Erigenia 15:3-95.

\section{Author Information}

Roberta (Mount) Flood

Former Conservation Resource

\section{Manager}

David Horvath

Nursery Manager

dave_horvath_at_con 084 p 8

@ dnrmail.state.il.us

Gary Blessman

former Propagation Technician

Mason State Nursery

Division of Forest Resources

Illinois Department of Natural

Resources

17855 N County Road, $2400 E$ Topeka, IL 61567 